Article

\title{
Knowledge and Perception of Rabies among School Children in Rabies Endemic Areas of South Bhutan
}

\author{
Lungten Lungten ${ }^{1,2,3, *}$, Sangay Rinchen ${ }^{4}$, Tenzin Tenzin ${ }^{4} \mathbb{D}$, Waraphon Phimpraphai ${ }^{1, *}$ \\ and Michel de Garine-Wichatitsky 1,5 (D)
}

1 Faculty of Veterinary Medicine, Kasetsart University, Bangkok 10900, Thailand; michel.de_garine-wichatitsky@cirad.fr

2 National Polytechnique Institute of Toulouse, 31076 Toulouse, France

3 City Veterinary Hospital and Satellite Laboratory, Dewathang, Samdrup Jongkhar 41001, Bhutan

4 National Centre of Animal Health, Department of Livestock, Thimphu 11001, Bhutan; srinchen@moaf.gov.bt (S.R.); tenzinvp@gmail.com (T.T.)

5 ASTRE, University Montpellier, CIRAD, INRAE, 34000 Montpellier, France

* Correspondence: trendrelzang2012@gmail.com (L.L.); warapim@gmail.com (W.P.); Tel.: +66-0991023894 or +975-17472015 (L.L.); +66-0818540091 (W.P.)

Citation: Lungten, L.; Rinchen, S.; Tenzin, T.; Phimpraphai, W.; de Garine-Wichatitsky, M. Knowledge and Perception of Rabies among School Children in Rabies Endemic Areas of South Bhutan. Trop. Med. Infect. Dis. 2021, 6, 28. https:// doi.org/10.3390/tropicalmed6010028

Received: 16 January 2021

Accepted: 18 February 2021

Published: 2 March 2021

Publisher's Note: MDPI stays neutral with regard to jurisdictional claims in published maps and institutional affiliations.

Copyright: (c) 2021 by the authors. Licensee MDPI, Basel, Switzerland. This article is an open access article distributed under the terms and conditions of the Creative Commons Attribution (CC BY) license (https:// creativecommons.org/licenses/by/ $4.0 /)$.

\begin{abstract}
Rabies is endemic in southern Bhutan and children are the frequent victims of dog bites. We surveyed the knowledge, attitude, and practices on rabies among school children in three schools located in southern Bhutan. A total of 701 students (57.9\% female, $42.1 \%$ male) with an age range of 12-21 years (mean: 15 years) participated in the survey, of which $98.2 \%$ had heard about rabies. Most of the students demonstrated a good level of knowledge $(59.7 \%)$ and a favorable perception towards rabies (57.7\%). Multivariable logistic analysis revealed the relation between knowledge and the awareness campaign (OR:1.5, 95\% CI: 1.1-2.1). Similarly, higher grades of students (OR:1.9, 95\%CI: 1.3-2.9) and employed mothers of the students (OR: 1.6, 95\% CI: 1.0-2.7) were associated with more favorable perceptions. However, some knowledge gaps were identified in this study, such as students not being able to clearly mention the susceptible hosts of rabies, transmission routes, clinical signs, and prevention and control options. Therefore, regular awareness programs on rabies are necessary among school children in Bhutan.
\end{abstract}

Keywords: rabies; school children; knowledge; attitude; practice; education; Bhutan

\section{Introduction}

Rabies is caused by infection with a lyssavirus and is one of the most important Neglected Tropical Diseases [1]. Rabies is transmitted mainly through dog bites and causes approximately 59,000 human deaths every year [2,3]. The disease is endemic in Asia and Africa and most of the victims are children (40\%) under the age of 15 years. This zoonosis results in economic losses of up to 8.6 billion USD annually and about 3 billion people are at risk of infection [2].

Rabies is $100 \%$ fatal once clinical signs appear. However, timely use of vaccine and rabies immune globulin (RIG), and appropriate post-exposure prophylaxis (PEP), can effectively prevent a productive viral infection [3]. Unfortunately, PEP is not easily accessible, especially to poor people and to remote rural communities in rabies endemic countries. Even when biologics are available, bite victims may not have the means to pay for transport to the hospital and cover the costs for PEP [2]. Inefficient health-seeking behavior of dog bite victims, such as seeking the assistance of traditional healers for local treatment at home, is also associated with a low level of knowledge and awareness about the health risk of rabies $[4,5]$.

In Bhutan, rabies is endemic in the southern part of the country that shares a border with India, and reports around 17 outbreaks every year [6]. Sporadic outbreaks are also reported from the eastern parts of the country $[7,8]$. Dog bites are common. Approximately 
7000 bite incidents are reported every year in the country, with a population of 700,000 people. Annually, the government spends approximately Nu 9.3 million (USD 142,000) on PEP- $[9,10]$. Seventeen human rabies death were reported between 2006 and 2016 [11]. One death was reported during 2020 in a three-year old child [12].

In Bhutan, PEP is provided free of charge to dog bite victims through a network of 240 health centers located across the country $[9,11]$. The general level of knowledge and awareness on rabies is thought to be high among the communities, which has been attributed to regular awareness programs $[7,9,10,13]$. However, children under the age of 15 years are at higher risk of experiencing dog bites and rabies deaths in Bhutan $[10,14]$. Little is known about their perceptions on rabies. As such, is important to understand the knowledge, attitudes, and practices (KAP) of school children regarding rabies and dog bites to design efficient prevention programs. In this study, we described the findings of a KAP survey on rabies among children in three secondary schools located in the rabies endemic zone of southern Bhutan and discuss possible prevention measures.

\section{Materials and Methods}

\subsection{Study Area}

The study was conducted in the three towns of southern and eastern Bhutan sharing a border with India: Phuntsholing, Gelephu, and Samdrup Jongkhar (Figure 1). These areas report frequent outbreaks of animal rabies [6] and have recorded a greater incidence of dog bites compared to the rest of the country $[9,14]$

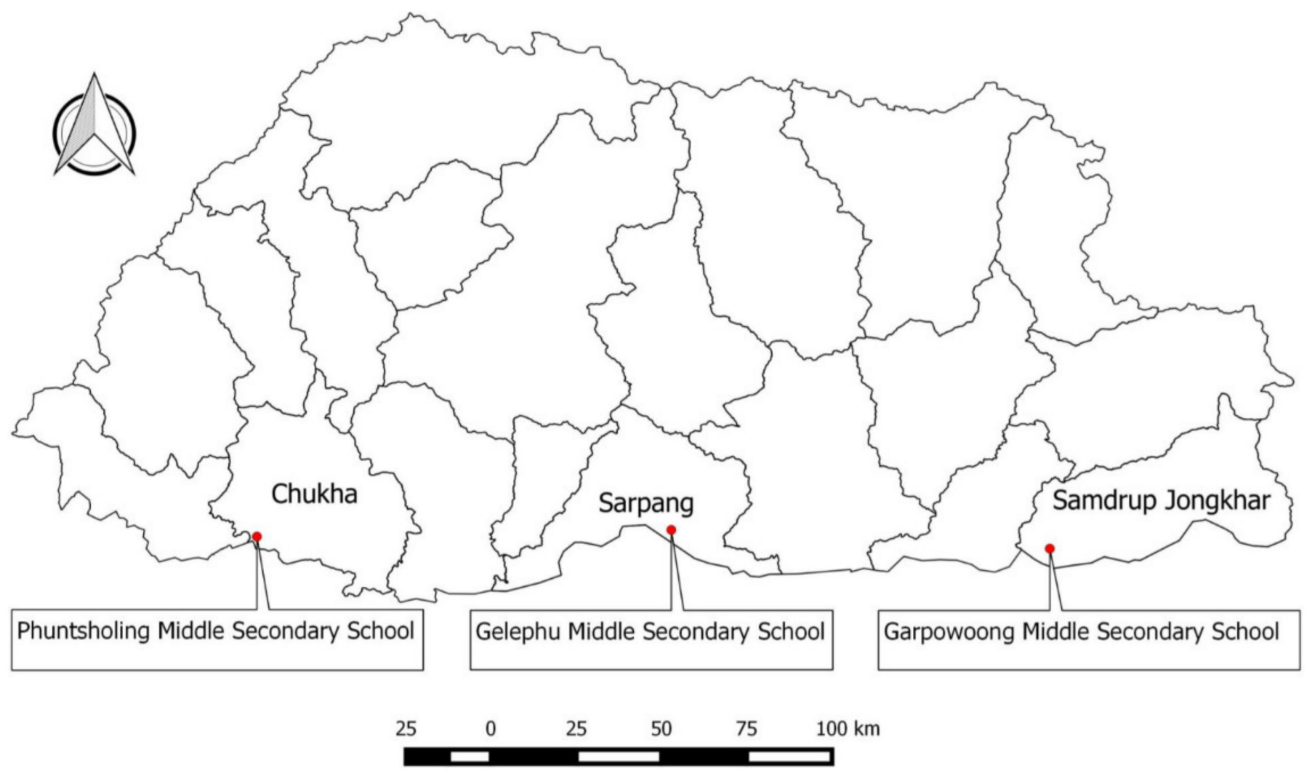

Figure 1. Map of Bhutan showing the location of three schools in which the study was conducted (Bhutan is located between China in the north and India in the south, east, and west). The names and borders of the districts are indicated as well as the location of the schools surveyed (red dots). The map was prepared using Quantum GIS, QGIS Development Team (2019), QGIS Geographic Information System, Open-Source Geospatial Foundation Project (http:/ / qgis.osgeo.org) and was not taken from another source.

Approximately 44,328 people live in the three towns [15]: Phuntsholing $(27,658)$, Gelephu (9858), and Samdrup Jongkhar $(10,545)$. There are 14 schools and approximately 7809 students studying in these towns [15]. Of these, six are Higher Secondary Schools, four Middle Secondary Schools (MSS), two Lower Secondary Schools, and two Primary schools. Four Higher Secondary Schools from these three areas are private schools. The rest are government public schools. 


\subsection{Study Design and Data Collection}

In Phuntsholing, Phuntsholing Middle Secondary School (PMSS) was selected based on access and convenience, because the school is located in the core town area and has a high-risk of dog bites due to the large number of free-roaming dogs in the town. In Gelephu, since there is only one MSS, Gelephu Middle Secondary School (GMSS) was included in the study. Similarly, from Samdrup Jongkhar, of the two MSS, Garpowoong Middle Secondary School (GaMSS) was selected at random for the study. Assuming that grade 8,9 , and 10 students understand and correctly interpret the questionnaires, they were invited to participate in the study. Data were collected using an individual structured questionnaire. The questionnaire consisted of three sections:

1. demographic details of students;

2. knowledge, attitude, and practices of students regarding rabies;

3. dog bite incidence and health-seeking behavior of the respondent students.

Before the actual survey, the questionnaires were pre-tested with 10 students of GaMSS and changes were made to improve the clarity of the questions. All students in grades 8,9 , and 10 from the selected schools were enrolled in the study. Prior to school visits, approvals were obtained from both the school principals and class teachers. Before the actual data collection, students were explained the purpose of the study, that participation was voluntary, and they were allowed to withdraw at any stage. After obtaining verbal and written consent from the students, questionnaires were distributed for self-administration. The questionnaires were explained to the students and they were guided in answering each question.

\subsection{Data Management and Analysis}

The questionnaire survey data were entered into a database developed in EpiInfo software version 7.2.3.1 [16]. The data were then extracted into Microsoft excel 2013 (Microsoft Excel, Redmon, WA, USA) and checked for any errors before performing the analysis (Table S1). Data analysis was performed with R statistical software version 3.6.1 using packages "dplyr", "descr", "forcats", "LogisticDx", and "ggplot2" [17]. Descriptive statistics were obtained by calculating the proportions, frequency, mean, median, standard deviation, and ranges. For analysis, variable age was categorized as "adolescent" for those students whose age was more than 15 years and "young" for those whose age was less than or equal to 15 using the mean age. The number of dogs owned by the students was categorized as " 1 dog" if they owned only one dog at home and "more than 1 dog" if the students reported that they owned more than one dog at home. The occupation of the parents of the students was collapsed into two categories using the "forcats" $R$ package. Those working in the military, government offices, and corporations were categorized together as "employed" and those that were working in business, as farmers, and others were considered as "self-employed." Frequencies of the categorical variables related to socio-demographic characteristics, dog ownership status, and dog bite incidence were compared between the three schools using Pearson's Chi-squared test with Yates' continuity correction and Fisher's Exact Test.

The knowledge of the students was assessed on sources of rabies, mode of transmissions, signs shown by rabid animals, and the preventive measures of rabies. For every correct answer (i.e., in agreement with the conventional medical knowledge on rabies), a score of " 1 " was allotted, and " 0 " was allotted for the wrong answers. The scoring method used is described in the Supplementary Materials (Table S1). Knowledge was based on the scores that students obtained in identifying rabies virus sources (1 point), susceptible hosts (5 points), mode of transmission ( 3 points), clinical signs (4 points), and rabies prevention measures ( 3 points). A maximum of 16 points was obtained if the students correctly answered all questions. The total scores obtained by each student were calculated and the total scores were categorized into binary outcome variables using the mean score of knowledge $[18,19]$. The students that had a knowledge score higher than the mean $(\geq 7)$ were considered as "Good" and those that had a lesser knowledge score than the mean 
$(<7)$ were considered as having "Poor" knowledge on rabies. Similarly, for the perception related questions, a score of " 1 " was allotted for the correct answers and " 0 " for the wrong answers. Perceptions were assessed on what students would do if they were bitten by dogs (3 points) and what they would do if they saw a dog with abnormal behavior ( 2 points). A maximum of five points were obtained if students correctly answered all the questions. If the perception scores were more than or equal to the mean $(\geq 3.5)$, they were considered as "Favorable," and if scores were less than the mean score $(<3.5)$, they were considered as an "Unfavorable" perception to rabies.

Logistic regression models were built separately for student knowledge and perception (binary outcome variables) to analyze if there was any association with the explanatory variables: socio-demographic characteristics, dog ownership status, dog bite incidence, and education status of the students (whether they have attended rabies awareness program previously). The explanatory variables that had a $p$-value $\leq 0.20$ in the univariable analysis were selected and used for the multivariable analysis. Only those variables that had $p$ value $\leq 0.05$ were retained in the final model. The goodness-of-fit for the model was assessed using the Hosmer Lemeshow test.

\subsection{Ethical Approvals}

The study was approved by the Research Ethics Board of Health, Ministry of Health (Ref. No. REBH/Approval/2019/113). Administrative approvals were also obtained from the city education officers, and from the three school principals and class teachers prior to the study.

\section{Results}

\subsection{Socio-Demographic Characteristics of the Students}

Of the 712 students invited to participate in the study, 701 students completed the survey $(98.0 \%)$. Data from these completed questionnaires were used for analyses. The final group of students who completed the questionnaires was comprised of $406(57.9 \%)$ females and $295(42.1 \%)$ males. The students' age ranged from 12 to 21 years (median: 15 years). The participants included 234 (43.4\%) students from PMSS, 237 (33.8\%) from GaMSS and 160 (22.8\%) from GMSS. Most study participants were studying in grade 9 ( $n=291,41.5 \%)$, followed by grade $10(n=256,36.5 \%)$ and $8(n=154,22.0 \%)$. Most students ( $n=490,69.90 \%$ ) resided in town with their parents and attended school as day-scholars. The socio-demographic details of the students are described in Table 1.

Among the 701 participants, $31.0 \%$ of the students owned dogs at their house $(n=217)$, with each household owing an average of 1.6 dogs. The proportion of households with dogs was significantly different between the schools $\left(\chi^{2}=17.5, \mathrm{df}=2, p\right.$-value $\left.<0.001\right)$, highest for students from GMSS $(n=83,38.0 \%)$ and lowest in PMSS $(n=63,29.0 \%)$. The students reported that the dogs that they owned were mostly given to them by neighbors $(n=115,53.0 \%)$, were vaccinated $(n=163,75.1 \%)$, and were allowed to roam freely $(n=121$, $55.8 \%)$. Vaccination status of the owned dogs was significantly different among different schools $(p=0.009)$ with more vaccinated dogs reported by the dog owning students from PMSS $(n=67,30.9 \%)$. Only one-third $(n=74,33.6 \%)$ of the students reported that their dogs were sterilized/neutered (Table 2). 
Table 1. Socio-demographic characteristics of the students that participated in the study from three middle secondary schools located in rabies endemic areas of Bhutan (PMSS: Phuntsholing Middle Secondary School; GMSS: Gelephu Middle Secondary School; GaMSS: Garpowoong Middle Secondary School).

\begin{tabular}{|c|c|c|c|c|c|}
\hline \multirow[b]{2}{*}{ Variables } & \multirow[b]{2}{*}{ Total $(n \%)$} & \multicolumn{3}{|c|}{ School Name ( $n(\%))$} & \multirow[b]{2}{*}{$\underset{p \text {-Value }}{\chi^{2}}$} \\
\hline & & GMSS & PMSS & GaMSS & \\
\hline Sex & & & & & 0.258 \\
\hline Male & $295(42.1)$ & $59(8.4)$ & $129(18.4)$ & $107(15.3)$ & \\
\hline Female & $406(57.9)$ & $101(14.4)$ & $175(25.0)$ & $130(18.5)$ & \\
\hline Age & & & & & 0.015 \\
\hline Young $(\leq 15$ yrs $)$ & $470(67.0)$ & $111(15.8)$ & $217(31.0)$ & $142(13.6)$ & \\
\hline Adolescent (>15 yrs.) & $231(33.0)$ & $49(7.0)$ & $87(12.4)$ & $95(13.6)$ & \\
\hline Grade in which student study & & & & & $<0.001$ \\
\hline Grade 8 & $154(22.0)$ & $42(6.0)$ & $34(4.9)$ & $78(11.1)$ & \\
\hline Grade 9 & $291(41.5)$ & $65(9.3)$ & $132(18.8)$ & $94(13.4)$ & \\
\hline Grade 10 & $256(36.5)$ & $53(7.6)$ & $138(19.7)$ & $65(9.3)$ & \\
\hline Hometown of Students & & & & & $<0.001$ \\
\hline Village & $211(30.1)$ & $77(11.0)$ & $37(5.3)$ & $97(13.8)$ & \\
\hline Town & $490(69.9)$ & $83(11.8)$ & $267(38.1)$ & $140(20.0)$ & \\
\hline Father's occupation & & & & & $<0.001$ \\
\hline Farmers & $102(14.6)$ & $31(4.4)$ & $11(1.6)$ & $60(8.6)$ & \\
\hline Businessman & $76(10.8)$ & $29(4.1)$ & $39(5.6)$ & $8(1.1)$ & \\
\hline Government employee & $127(18.1)$ & $30(4.3)$ & $75(10.7)$ & $22(3.1)$ & \\
\hline Private/corporate employee & $112(16.0)$ & $17(2.4)$ & $86(12.3)$ & $9(1.3)$ & \\
\hline Military & $209(29.8)$ & $27(3.9)$ & $69(9.8)$ & $113(16.1)$ & \\
\hline Others & $75(10.7)$ & $26(3.7)$ & $24(3.4)$ & $25(3.6)$ & \\
\hline Mother's occupation & & & & & $<0.001$ \\
\hline Farmers & $103(14.7)$ & $32(4.7)$ & $11(1.6)$ & $60(8.6)$ & \\
\hline Businesswoman & $64(9.1)$ & $25(3.6)$ & $33(4.7)$ & $6(0.9)$ & \\
\hline Government employee & $59(8.4)$ & $12(1.7)$ & $40(5.7)$ & $7(1.0)$ & \\
\hline Private/corporate employee & $27(3.9)$ & $3(0.4)$ & $22(3.1)$ & $2(0.3)$ & \\
\hline Military & $2(0.3)$ & $0(0.0)$ & $1(0.1)$ & $1(0.1)$ & \\
\hline Housewife & $431(61.5)$ & $83(11.8)$ & $190(27.1)$ & $158(22.5)$ & \\
\hline Others & $15(2.1)$ & $5(0.7)$ & $7(1.0)$ & $3(0.4)$ & \\
\hline Dog ownership & & & & & $<0.001$ \\
\hline No & $484(69.0)$ & $89(12.7)$ & $221(31.5)$ & $174(24.8)$ & \\
\hline Yes & $217(31.0)$ & $71(10.1)$ & $83(11.8)$ & $63(9.0)$ & \\
\hline
\end{tabular}

Table 2. Characteristics and management of dogs owned by students' households in three rabies endemic towns of Bhutan ( $n$ = 217; Phuntsholing, Gelephu, Garpowoong).

\begin{tabular}{|c|c|c|c|c|c|}
\hline \multirow{2}{*}{$\begin{array}{l}\text { Characteristics of Dog } \\
\text { Owning Students }\end{array}$} & \multirow[b]{2}{*}{ Total } & \multicolumn{3}{|c|}{ School } & \multirow{2}{*}{$\begin{array}{c}\chi^{2} \\
p \text {-Value }\end{array}$} \\
\hline & & GMSS & PMSS & GaMSS & \\
\hline Dog source & & & & & $p<0.001$ \\
\hline Adopted from street & $31(14.3)$ & $8(3.7)$ & $8(3.7)$ & $15(6.9)$ & \\
\hline Given by neighbor/friends & $115(53.0)$ & $28(12.9)$ & $54(24.9)$ & $33(15.2)$ & \\
\hline Purchased within Bhutan & $28(12.9)$ & $12(5.5)$ & $11(5.1)$ & $5(2.3)$ & \\
\hline Purchased from outside country & $4(1.8)$ & $0(0.0)$ & $4(1.8)$ & $0(0.0)$ & \\
\hline I don't know & $37(17.1)$ & $23(10.6)$ & $5(2.3)$ & $9(4.2)$ & \\
\hline Missing & $2(0.9)$ & $0(0.0)$ & $1(0.5)$ & $1(0.5)$ & \\
\hline Dog number & & & & & $p=0.048$ \\
\hline One dog & $154(71.0)$ & $43(19.8)$ & $65(30.0)$ & $46(21.2)$ & \\
\hline More than one dog & $63(29.0)$ & $28(1.9)$ & $18(8.3)$ & $17(7.8)$ & \\
\hline Dog keeping practices & & & & & $p<0.001$ \\
\hline Free roaming all the time & $54(24.9)$ & $24(11.1)$ & $14(6.5)$ & $16(7.4)$ & \\
\hline Keep inside house compound all the time & $94(43.3)$ & $26(12.0)$ & $52(24.0)$ & $16(7.4)$ & \\
\hline Roam freely outside during day-time & $65(30.0)$ & $21(9.7)$ & $16(7.4)$ & $28(12.9)$ & \\
\hline Roam freely during night-time & $2(0.9)$ & $0(0.0)$ & $0(0.0)$ & $2(0.9)$ & \\
\hline Missing & $2(0.9)$ & $0(0.0)$ & $1(0.5)$ & $1(0.5)$ & \\
\hline Dog vaccination status * & & & & & $p=0.009$ \\
\hline
\end{tabular}


Table 2. Cont.

\begin{tabular}{|c|c|c|c|c|c|}
\hline \multirow{2}{*}{$\begin{array}{l}\text { Characteristics of Dog } \\
\text { Owning Students }\end{array}$} & \multirow[b]{2}{*}{ Total } & \multicolumn{3}{|c|}{ School } & \multirow{2}{*}{$\underset{p \text {-Value }}{\chi^{2}}$} \\
\hline & & GMSS & PMSS & GaMSS & \\
\hline No & $26(12.0)$ & $14(6.5)$ & $4(1.8)$ & $8(3.7)$ & \\
\hline Yes & $163(75.1)$ & $45(20.7)$ & $67(30.9)$ & $51(23.5)$ & \\
\hline I don't know & $26(12.0)$ & $12(5.5)$ & $11(5.1)$ & $3(1.4)$ & \\
\hline Missing & $2(0.9)$ & $0(0.0)$ & $1(0.5)$ & $1(0.5)$ & \\
\hline Dog sterilized * & & & & & $p=0.239$ \\
\hline No & $89(41.0)$ & $33(15.2)$ & $26(12.0)$ & $30(13.8)$ & \\
\hline Yes & $73(33.6)$ & $24(11.1)$ & $30(13.8)$ & $19(8.8)$ & \\
\hline I don't know & $53(24.4)$ & $14(6.5)$ & $26(12.0)$ & $13(6.0)$ & \\
\hline Missing & $2(0.9)$ & $0(0.0)$ & $1(0.5)$ & $1(0.5)$ & \\
\hline
\end{tabular}

Note: ${ }^{*}$ The frequency and percentage are based on the student's responses.

\subsection{Dog Bites Incidence and Health-Seeking Behaviour}

The study found that 111 students $(15.8 \%)$ had experienced dog bites in the last two years prior to the study period. Most bites were sustained from pet dogs $(n=58,52.3 \%)$ compared to stray dogs $(n=44,39.6 \%)$ with five students $(n=5,4.5 \%)$ unable to ascertain the status of dog that bit them. Thirty students $(50.0 \%)$ reported bites by pet dogs belonging to their neighbors. Most bite victims $(n=64,57.7 \%)$ reported that they were bitten without any disturbance or provocation of the dog. Most unprovoked bites were reported from PMSS $(n=35,31.5 \%)$, which is significantly higher than other two schools $(p=0.006)$. Regarding the care given after bites, the majority of students indicated that they washed the bite wound with soap and water $(n=69,62.2 \%)$, visited hospitals $(n=49,84.7 \%)$ and received PEP $(n=92,82.9 \%)$. However, adoption of risky practices were also reported, such as application of local medicine, not visiting hospitals $(n=13,11.7 \%)$, and non-completion of the complete vaccine schedule $(n=3,3.2 \%)$. When asked about the fate of the dog that had bitten them, the majority of the victims $(n=56,50.5 \%)$ reported that the dog was still alive, while twenty-three students (20.7\%) could not ascertain the status of the dog and eighteen students $(16.2 \%)$ reported that dog had died, but were unable to say if the dog had died because of rabies or other diseases (Table 3).

Table 3. Characteristics of dog bites and health-seeking behaviors among students bitten by dogs $(n=111)$.

\begin{tabular}{|c|c|c|c|c|c|}
\hline \multirow{2}{*}{ Variables } & \multirow[b]{2}{*}{ Total } & \multicolumn{3}{|c|}{ Schools } & \multirow{2}{*}{$\begin{array}{c}\chi^{2} \\
p \text {-Value }\end{array}$} \\
\hline & & GMSS & PMSS & GaMSS & \\
\hline \multicolumn{6}{|c|}{ What type of dog bit you? } \\
\hline Pet dog & $58(52.3)$ & $15(13.5)$ & $31(27.9)$ & $12(10.8)$ & \multirow{4}{*}{$p=0.59$} \\
\hline Stray dog & $44(39.6)$ & $7(6.3)$ & $27(24.3)$ & $10(9.0)$ & \\
\hline I don't know & $5(4.5)$ & $0(0.0)$ & $4(3.6)$ & $1(0.9)$ & \\
\hline Missing & $4(3.6)$ & $0(0.0)$ & $2(1.8)$ & $2(1.8)$ & \\
\hline \multicolumn{6}{|c|}{ What was the reason for the bite? } \\
\hline Provoked bite & $43(38.7)$ & $13(11.7)$ & $27(24.3)$ & $3(2.7)$ & \multirow{3}{*}{$p=0.006$} \\
\hline Unprovoked bite & $64(57.7)$ & $9(8.1)$ & $35(31.5)$ & $20(18.0)$ & \\
\hline Missing & $4(3.6)$ & $0(0.0)$ & $2(1.8)$ & $2(1.8)$ & \\
\hline \multicolumn{6}{|c|}{$\begin{array}{l}\text { What happened to the biting dog within } \\
\text { three month after the bite? }\end{array}$} \\
\hline Died & $18(16.2)$ & $6(5.4)$ & $9(8.1)$ & $3(2.7)$ & \multirow{6}{*}{$p=0.091$} \\
\hline Disappeared & $9(8.1)$ & $0(0.0)$ & $7(6.3)$ & $2(1.8)$ & \\
\hline dog still alive & $56(50.5)$ & $12(10.8)$ & $28(25.2)$ & $16(14.4)$ & \\
\hline The dog was killed & $1(0.9)$ & $1(0.9)$ & $0(0.0)$ & $0(0.0)$ & \\
\hline I don't know & $23(20.7)$ & $3(2.7)$ & $18(16.2)$ & $2(1.8)$ & \\
\hline Missing & $4(3.6)$ & $0(0.0)$ & $2(1.8)$ & $2(1.8)$ & \\
\hline
\end{tabular}


Table 3. Cont.

\begin{tabular}{|c|c|c|c|c|c|}
\hline \multirow{2}{*}{ Variables } & \multirow[b]{2}{*}{ Total } & \multicolumn{3}{|c|}{ Schools } & \multirow{2}{*}{$\underset{p \text {-Value }}{\chi^{2}}$} \\
\hline & & GMSS & PMSS & GaMSS & \\
\hline \multicolumn{6}{|l|}{ What did you do to the bite wound? } \\
\hline Applied antiseptics to the wound & $5(4.5)$ & $1(0.9)$ & $4(3.6)$ & $0(0.0)$ & \multirow{6}{*}{$p=0.130$} \\
\hline Applied local herbs/medicine & $13(11.7)$ & $7(6.3)$ & $3(2.7)$ & $3(2.7)$ & \\
\hline Washed bite wound with soap and water & $69(62.2)$ & $11(9.9)$ & $41(36.9)$ & $17(15.3)$ & \\
\hline Washed bite wound with water only & $12(10.8)$ & $2(1.8)$ & $8(7.2)$ & $2(1.8)$ & \\
\hline I did nothing & $8(7.2)$ & $1(0.9)$ & $6(5.4)$ & $1(0.9)$ & \\
\hline Missing & $4(3.6)$ & $0(0.0)$ & $2(1.8)$ & $2(1.8)$ & \\
\hline \multicolumn{6}{|l|}{ Have you visited a hospital after the bite? } \\
\hline Yes & $94(84.7)$ & $22(19.8)$ & $51(46.0)$ & $21(18.9)$ & \multirow{3}{*}{$p=0.098$} \\
\hline No & $13(11.7)$ & $0(0.0)$ & $11(9.9)$ & $2(1.8)$ & \\
\hline Missing & $4(3.6)$ & $0(0.0)$ & $2(1.8)$ & $2(1.8)$ & \\
\hline \multicolumn{6}{|l|}{ Did you receive rabies vaccine injections? } \\
\hline Yes & $92(82.9)$ & $21(18.9)$ & $50(45.1)$ & $21(18.9)$ & \multirow{3}{*}{$p=0.230$} \\
\hline No & $15(13.5)$ & $1(0.9)$ & $12(10.8)$ & $2(1.8)$ & \\
\hline Missing & $4(3.6)$ & $0(0.0)$ & $2(1.8)$ & $2(1.8)$ & \\
\hline
\end{tabular}

\subsection{Students' Knowledge Regarding Rabies}

Most students had heard about rabies ( $n=688,98.2 \%)$. The sources of information (Figure 2) were from health workers ( $n=488,70.9 \%)$, teachers $(n=449,65.3 \%)$ and friends $(n=362,52.6 \%)$. Among those who had heard about rabies, the majority $(n=622,90.4 \%)$ knew that dog is the main source of rabies in Bhutan. However, few students mentioned that other animals, such as bats $(n=36,5.2 \%)$, cats $(n=3,0.4 \%)$, cows $(n=1,0.1 \%)$ and birds $(n=2,0.3 \%)$, are the main source of rabies.

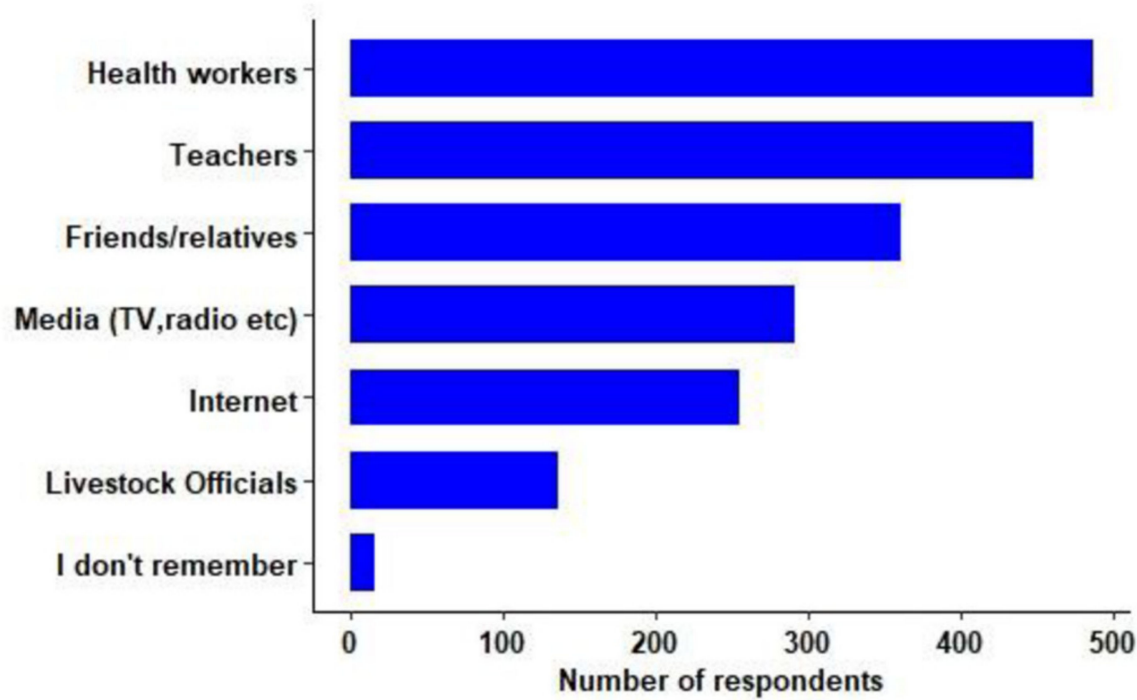

Figure 2. Sources of rabies information for the students of three secondary schools located in rabies endemic areas of south Bhutan (Phuntsholing, Gelephu, Garpowoong; $n=701$ ).

Regarding the causes of rabies (Figure 3a), most of the students ( $n=399,58.0 \%)$ correctly identified viruses as the cause of rabies (Table 4 ), although some students associated rabies to other factors such as bacteria $(n=326,47.4 \%)$, eating food or poison $(n=256$, $37.2 \%)$, psychological problems $(n=189,27.5 \%)$, starvation and thirst $(n=109,15.8 \%)$, and Spirits $(n=28,4.1 \%)$. 

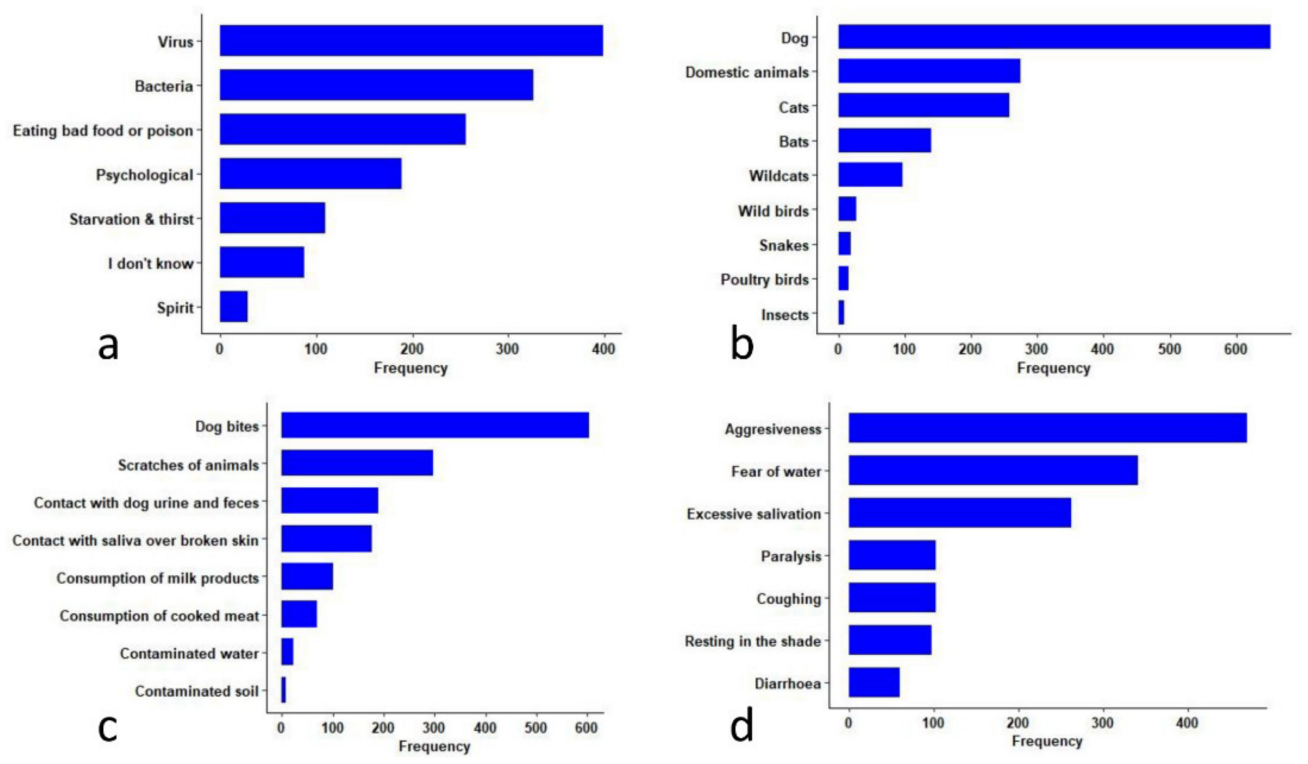

Figure 3. Knowledge on rabies among the students from study areas in South Bhutan: (a) knowledge on causes of rabies mentioned by the students; (b) knowledge on the susceptible hosts of rabies mentioned by the students; (c), knowledge on the mode of transmission of rabies mentioned by the students; and (d) knowledge on the clinical signs of rabies mentioned by the students. Each bar in the graph represents frequency of the positive responses by total students who heard about rabies $(n=688)$ to the specific cause, hosts, routes, and clinical signs of rabies.

When asked about the susceptible host of rabies, almost all students $(n=651,94.6 \%)$ mentioned that dogs are the main susceptible host for rabies. They also correctly identified other domestic mammals like cattle, pigs, and horses $(n=275,40.0 \%)$, domestic cats $(n=256,37.5 \%)$, bats $(n=140,20.4 \%)$, and wild cats, such as tigers and leopards ( $n=97$, $14.1 \%)$ as susceptible hosts for rabies. However, some of the students surveyed answered that wild birds $(n=27,3.9 \%)$, snakes $(n=19,2.8 \%)$, poultry $(n=16,2.3 \%)$, and insects $(n=9,1.3 \%)$ can also be affected by rabies (Table 4, Figure $3 b)$, which is not in agreement with conventional veterinary knowledge. When asked if rabies can infect humans, 636 (92.4\%) students knew that humans could be infected, but 397 (57.7\%) students were not able to ascertain the fatal nature of the disease when symptoms appear.

Regarding the transmission of rabies virus, 603 (87.7\%) students understood that rabies can be transmitted through dog bites. Other possible transmission routes such as scratches due to animals and contact with saliva over broken skin were mentioned by 297 $(43.2 \%)$ and $176(25.6 \%)$ students, respectively. Transmission routes through consumption of milk products $(n=101,14.7 \%)$, cooked meat $(n=68,9.9 \%)$, contact with dog urine and feces $(n=190,27.6 \%)$, contaminated water $(n=23,3.3 \%)$ and contaminated soil $(n=8$, $1.16 \%$ ) were also reported (Table 4, Figure 3c), although these transmission routes are not in agreement with conventional veterinary knowledge.

Regarding clinical signs of rabies (Table 4, Figure 3d), most of the students mentioned that a rabid animal is aggressive $(n=470,68.3 \%)$, fears water $(n=341,49.6 \%)$, and excessively salivates $(n=262,38.1 \%)$. Signs that were not usually associated with rabies, such as coughing $(n=102,14.8 \%)$ and diarrhea $(n=60,8.7 \%)$ were also reported by some students.

Most students knew that rabies in dogs can be prevented by vaccination $(n=452$, $65.7 \%)$. Regarding the frequency of vaccination, $560(81.4 \%)$ students mentioned that dogs should be vaccinated every year, while $105(16.3 \%)$ students did not know the required frequency of vaccination. Few students $(n=20,2.9 \%)$ mentioned that only one-time vaccination was needed in the dog's lifetime, while three students $(0.4 \%)$ mentioned that vaccination was not necessary. Other methods, such as preventing dogs from contacting stray dogs $(n=67,9.7 \%)$, washing the dog with shampoo $(n=67,9.7 \%)$, not allowing the 
dogs to feed on garbage $(n=54,7.9 \%)$, and regular deworming $(n=19,2.8 \%)$, were also mentioned by some students as preventive measures for rabies.

Table 4. Student level of knowledge regarding rabies and perception towards dog bite management and rabid dog.

\begin{tabular}{|c|c|c|c|c|c|}
\hline \multicolumn{6}{|c|}{ Knowledge on Rabies } \\
\hline \multirow[t]{2}{*}{ Variable } & \multirow{2}{*}{ Frequency (\%) } & \multicolumn{3}{|c|}{ School Name } & \multirow{2}{*}{$\begin{array}{c}\chi^{2} \\
p \text {-Value }\end{array}$} \\
\hline & & GMSS & PMSS & GaMSS & \\
\hline \multicolumn{6}{|l|}{ Knowledge on causes of rabies } \\
\hline Psychological & $189(27.5)$ & $47(6.8)$ & $78(11.3)$ & $64(9.3)$ & 0.678 \\
\hline Associated with spirit & $28(4.1)$ & $6(0.9)$ & $7(1.0)$ & $15(2.2)$ & 0.065 \\
\hline Virus & $399(58.0)$ & $99(14.4)$ & $150(21.8)$ & $150(21.8)$ & 0.002 \\
\hline Starvation and thirst & $109(15.8)$ & $31(4.5)$ & $47(6.8)$ & $31(5.5)$ & 0.208 \\
\hline Bacteria & $326(47.4)$ & $78(11.3)$ & $138(20.1)$ & $110(16.0)$ & 0.756 \\
\hline Eating bad food or poison & $256(37.2)$ & $62(9.0)$ & $110(16.0)$ & $84(12.2)$ & 0.723 \\
\hline I don't know & $87(12.7)$ & $16(2.3)$ & $55(8.0)$ & $16(2.3)$ & $<0.001$ \\
\hline \multicolumn{6}{|l|}{ Knowledge on susceptible host of rabies } \\
\hline Bat & $140(20.4)$ & $47(6.8)$ & $49(7.1)$ & $44(6.4)$ & 0.002 \\
\hline Wild birds & $27(3.9)$ & $7(1.0)$ & $15(2.2)$ & $5(0.7)$ & 0.208 \\
\hline Dog & $651(94.6)$ & $147(21.4)$ & $280(40.7)$ & $224(32.7)$ & 0.843 \\
\hline Domestic animals (cow, pig, horse etc.) & $275(40.0)$ & $52(7.6)$ & $80(11.6)$ & $43(12.4)$ & $<0.001$ \\
\hline Cat & $258(37.5)$ & $70(10.2)$ & $103(15.0)$ & $85(12.4)$ & 0.091 \\
\hline Insects & $9(1.3)$ & $1(0.1)$ & $6(0.9)$ & $2(0.3)$ & 0.509 \\
\hline Poultry & $16(2.3)$ & $3(0.4)$ & $12(1.7)$ & $1(0.2)$ & 0.014 \\
\hline Snake & $19(2.8)$ & $6(0.9)$ & $9(1.3)$ & $4(0.6)$ & 0.396 \\
\hline Wild cats (tiger, leopard etc.) & $97(14.1)$ & $34(4.9)$ & $38(5.5)$ & $25(3.6)$ & 0.006 \\
\hline \multicolumn{6}{|l|}{$\begin{array}{c}\text { Knowledge on mode of transmission } \\
\text { of rabies }\end{array}$} \\
\hline Consumption of cooked meats & $68(9.9)$ & $10(1.5)$ & $20(2.9)$ & $38(5.5)$ & $<0.001$ \\
\hline Consumptions of milk products & $101(14.7)$ & $14(2.0)$ & $17(2.5)$ & $70(10.2)$ & $<0.001$ \\
\hline Contact with dog urine and feces & $190(27.6)$ & $33(4.8)$ & $88(12.8)$ & $69(10.0)$ & 0.121 \\
\hline Contact with saliva over broken skin & $176(25.6)$ & $34(4.9)$ & $62(9.0)$ & $80(11.6)$ & 0.001 \\
\hline Dog bites & $603(87.7)$ & $144(20.9)$ & $244(35.5)$ & $215(31.3)$ & $<0.001$ \\
\hline From contaminated water & $23(3.3)$ & $7(1.0)$ & $6(0.9)$ & $10(1.5)$ & 0.241 \\
\hline From contaminated soil & $8(1.2)$ & $3(0.4)$ & $4(0.6)$ & $1(0.2)$ & 0.383 \\
\hline Scratches of animals & $297(43.2)$ & $77(11.2)$ & $127(18.5)$ & $93(13.5)$ & 0.158 \\
\hline \multicolumn{6}{|l|}{$\begin{array}{l}\text { Knowledge on clinical signs of rabies } \\
\text { in dog }\end{array}$} \\
\hline Aggressiveness and tendency to bite & $470(68.3)$ & $111(16.1)$ & $215(31.3)$ & $144(20.9)$ & 0.016 \\
\hline Coughing & $102(14.8)$ & $22(3.2)$ & $46(6.7)$ & $34(4.9)$ & 0.907 \\
\hline Diarrhea & $60(8.7)$ & $14(2.0)$ & $31(4.5)$ & $15(2.2)$ & 0.256 \\
\hline Excessive salivation & $262(38.1)$ & $74(10.8)$ & $94(13.7)$ & $94(13.7)$ & 0.003 \\
\hline Fear of water & $341(49.6)$ & $87(12.6)$ & $112(16.3)$ & $142(20.6)$ & $<0.001$ \\
\hline Paralysis of leg & $103(15.0)$ & $23(3.3)$ & $49(7.1)$ & $31(4.5)$ & 0.567 \\
\hline Resting in the shade & $98(14.2)$ & $21(3.1)$ & $49(7.1)$ & $28(4.1)$ & 0.308 \\
\hline \multicolumn{6}{|c|}{ Perception on post bite cares and rabid dogs } \\
\hline \multicolumn{6}{|l|}{$\begin{array}{l}\text { What should you do if you are bitten } \\
\text { by dogs? }\end{array}$} \\
\hline Wash with soap and water for $15 \mathrm{~min}$ & $598(86.9)$ & $124(18.0)$ & $259(37.6)$ & $215(31.3)$ & 0.003 \\
\hline Go to the hospital and get vaccination & $635(92.3)$ & $149(21.7)$ & $266(38.7)$ & $220(32.0)$ & 0.05 \\
\hline Do the local treatment & $65(9.5)$ & $14(2.0)$ & $25(3.6)$ & $26(3.8)$ & 0.569 \\
\hline Do nothing and allow wound to heal & $5(0.7)$ & $2(0.3)$ & $2(0.3)$ & $1(0.1)$ & 0.726 \\
\hline \multicolumn{6}{|c|}{ What will you do if you see dog with aggressive behavior? } \\
\hline Kill the dog & $23(3.3)$ & $8(1.2)$ & $7(1.0)$ & $8(1.2)$ & 0.008 \\
\hline Report to teachers & $104(15.1)$ & $34(4.9)$ & $48(3.2)$ & $22(3.2)$ & 0.002 \\
\hline Report to livestock officers & $427(62.1)$ & $108(15.7)$ & $169(21.8)$ & $150(21.8)$ & 0.029 \\
\hline Take for treatments to animal hospital & $472(68.6)$ & $108(15.7)$ & $197(28.6)$ & $167(24.3)$ & 0.496 \\
\hline Do nothing & $72(10.5)$ & $14(2.0)$ & $43(6.3)$ & $15(2.2)$ & 0.008 \\
\hline
\end{tabular}




\subsection{Students' Perception towards Post-Bite Care and Rabid Dogs}

The details of what students would do if they were bitten by rabid dogs and what they would do if they saw a rabid dog in the streets are illustrated in Table 4 and Figure 4. Most students reported that they would wash the bite wound with soap and water $(n=598$, $86.9 \%)$ and go to the hospital to get PEP $(n=635,92.3 \%)$. However, risky practices, such as applying local medicines only $(n=65,9.5 \%)$ and doing nothing $(n=5,0.7 \%)$ to the bite wound were also reported. If they saw a dog suspected of rabies in streets, $472(68.6 \%)$ students indicated that they would try to catch the dog and take it to the animal hospital for treatment. Attitudes for other behaviors, such as reporting to the livestock officers ( $n=427,62.1 \%)$, reporting to their teachers $(n=104,12.0 \%)$, doing nothing $(n=72,10.5 \%)$, and killing the dogs $(n=23,3.3 \%)$ were also reported.
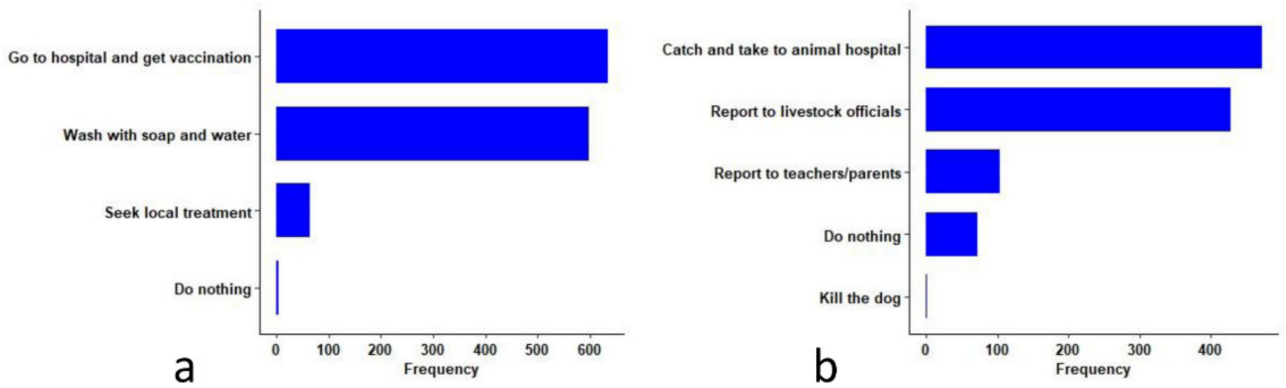

Figure 4. Students' perceptions on rabies: (a) what they would do if they were bitten by a rabid dog; (b) what they would do if they saw rabid dog in the streets. Each bar in the graph represents frequency of the positive responses by total students who heard about rabies $(n=688)$ to the specific cause, hosts, routes, and clinical signs of rabies.

\subsection{Logistic Regression Analyses}

The results of the univariable and multivariable analysis of factors associated with the knowledge and perception of the students are presented in Table 5 . The mean knowledge score of the students was 7.1 ( $\mathrm{SD}=2.0)$. The distribution of knowledge scores among the students from the three schools are given in Figure 5a. Significant differences were observed in the knowledge scores of the students between the three different schools, with students of GMSS (mean score $=7.6$ ) scoring higher than students of GaMSS (mean score $=7.2$ ) and PMSS (mean score $=6.6)(p<0.001)$. Using the cut-off score of $\geq 7$ (mean), 411 of $688(59.7 \%)$ students were classified as having a "good" knowledge score and $277(40.3 \%)$ as having a "poor" knowledge score on rabies. The final model, after adjusting for sex, indicated that students who had attended rabies awareness programs prior to the survey (Adjusted Odd Ratio: 1.5, 95\% CI: 1.1-2.1) had higher odds of having good knowledge compared to those that had not attended such a program. Similarly, students who were studying in grade 9 (AOR:1.1,95\% CI: 0.8-1.8) and grade 10 (AOR:1.7. 95\%CI:1.1-2.6) were more likely to have a good rabies knowledge compared with students studying in grade 8. Among the schools, students from PMSS (AOR: 0.7, 95\% CI: 0.4-1.5) and from GaMSS (AOR: 0.5, 95\% CI: 0.3-0.8) were less likely to have a good level of rabies knowledge compared to the students of GMSS.

The mean perception score was 3.5 (SD: 0.8 , median: 4) with a minimum score of 1 and a maximum of 5 . No significant differences were observed in the perception scores by the students among the three schools $(p=0.327)$. The mean scores of each class in different schools are presented in Figure $5 \mathrm{~b}$. Using the cut-off score of $\geq 3.5$ (mean) to classify into a "favorable" and "unfavorable" perception score, 397 of 688 (57.7\%) students were classified as having a favorable perception on rabies, and $291(42.3 \%)$ as unfavorable. After adjusting for sex and school, favorable attitudes and perceptions towards rabies were found significantly associated with grades (higher for grade 10; AOR: 1.9, 95\%CI: 1.3-3.2) and the mother's occupation (higher for employed mother; AOR: 1.7, 95\%CI: 1.0-2.8). 
Table 5. Logistic regression model showing the variables associated with the knowledge and perception level of the students on rabies $(n=688)$.

\begin{tabular}{|c|c|c|c|c|c|c|c|c|}
\hline \multicolumn{9}{|c|}{ Knowledge Level of Students on Rabies } \\
\hline \multirow{2}{*}{ Variables } & \multirow{2}{*}{ Category } & \multicolumn{2}{|c|}{$\begin{array}{c}\text { Adequate } \\
\text { Knowledge }\end{array}$} & \multirow{2}{*}{ Total } & \multirow{2}{*}{$\begin{array}{c}\begin{array}{c}\text { Univariable } \\
\text { Analysis }\end{array} \\
\text { OR } \\
(95 \% \mathrm{CI})\end{array}$} & \multirow{2}{*}{$p$-Value } & \multirow{2}{*}{$\begin{array}{c}\text { Multivariable } \\
\text { Analysis } \\
\text { Adjusted } \\
\text { OR (95\%CI) }\end{array}$} & \multirow{2}{*}{$p$-Value } \\
\hline & & No & Yes & & & & & \\
\hline \multirow{3}{*}{ School } & GMSS & 78 & 78 & 156 & Reference & Reference & Reference & Reference \\
\hline & PMSS & 192 & 105 & 297 & $0.6(0.4-0.8)$ & 0.003 & $0.7(0.4-1.1)$ & 0.001 \\
\hline & GaMSS & 141 & 94 & 235 & $0.7(0.4-1.0)$ & 0.051 & $0.6(0.3-0.8)$ & 0.039 \\
\hline \multirow{3}{*}{$\begin{array}{l}\text { Grade in which } \\
\text { student study }\end{array}$} & Grade 8 & 97 & 54 & 151 & Reference & Reference & Reference & Reference \\
\hline & Grade 9 & 177 & 107 & 284 & $1.1(0.7-1.6)$ & 0.694 & $1.1(0.8-1.8)$ & 0.535 \\
\hline & Grade 10 & 137 & 116 & 253 & $1.5(1.0-2.3)$ & 0.047 & $1.7(1.1-2.6)$ & 0.02 \\
\hline \multirow{2}{*}{$\begin{array}{l}\text { Attended rabies } \\
\text { awareness program }\end{array}$} & No & 268 & 151 & 419 & Reference & Reference & Reference & Reference \\
\hline & Yes & 143 & 126 & 269 & $1.6(1.2-2.1)$ & 0.017 & $1.5(1.1-2.1)$ & 0.009 \\
\hline \multirow{2}{*}{ Sex } & Female & 236 & 164 & 400 & Reference & Reference & Reference & Reference \\
\hline & Male & 175 & 113 & 288 & $0.9(0.7-1.3)$ & 0.641 & $0.9(0.7-1.3)$ & 0.857 \\
\hline \multirow{2}{*}{ Age } & Adolescent & 132 & 96 & 288 & Reference & Reference & & \\
\hline & Young & 279 & 181 & 460 & $0.9(0.6-1.2)$ & 0.018 & & \\
\hline \multicolumn{9}{|c|}{ Perception Level of Students on Rabies } \\
\hline \multirow{2}{*}{ Variables } & \multirow{2}{*}{ Category } & \multicolumn{2}{|c|}{$\begin{array}{l}\text { Favorable } \\
\text { Perception }\end{array}$} & \multirow{2}{*}{ Total } & $\begin{array}{c}\text { Univariable } \\
\text { Analysis }\end{array}$ & & $\begin{array}{c}\text { Multivariable } \\
\text { Analysis }\end{array}$ & \multirow{2}{*}{$\begin{array}{c}p \text {-Value } \\
\text { (Multivariable } \\
\text { Analysis) }\end{array}$} \\
\hline & & No & Yes & & $\begin{array}{c}\text { OR } \\
(95 \% \mathrm{CI})\end{array}$ & & $\begin{array}{c}\text { Adjusted } \\
\text { OR }(95 \% C I)\end{array}$ & \\
\hline \multirow{2}{*}{ Mother occupation } & Self employed & 264 & 339 & 603 & Reference & Reference & Reference & Reference \\
\hline & Employed & 27 & 58 & 85 & $1.7(1.0-2.8)$ & 0.037 & $1.7(1.0-2.8)$ & 0.031 \\
\hline \multirow{3}{*}{$\begin{array}{l}\text { Grade in which } \\
\text { student study }\end{array}$} & Grade 8 & 72 & 79 & 151 & Reference & Reference & Reference & Reference \\
\hline & Grade 9 & 138 & 146 & 284 & $1.0(0.7-1.4)$ & 0.857 & $1.00(0.7-1.5)$ & 0.881 \\
\hline & Grade 10 & 81 & 172 & 253 & $1.9(1.3-2.9)$ & 0.002 & $1.9(1.3-3.2)$ & 0.001 \\
\hline \multirow{2}{*}{ Sex } & Female & 169 & 231 & 400 & Reference & Reference & Reference & Reference \\
\hline & Male & 122 & 166 & 288 & $1.0(0.7-1.4)$ & 0.977 & $1.0(0.7-1.3)$ & 0.848 \\
\hline \multirow{3}{*}{ School } & GMSS & 63 & 93 & 156 & Reference & Reference & Reference & Reference \\
\hline & PMSS & 129 & 168 & 297 & $0.9(.06-1.3)$ & 0.533 & $0.8(0.5-1.3)$ & 0.401 \\
\hline & GaMSS & 99 & 136 & 235 & $0.9(0.6-1.4)$ & 0.976 & $1.0(0.7-1.5)$ & 0.937 \\
\hline \multirow{2}{*}{ Age } & Adolescent & 132 & 96 & 288 & Reference & Reference & & \\
\hline & Young & 279 & 181 & 460 & $0.7(0.5-1.0)$ & $<0.001$ & & \\
\hline \multirow{2}{*}{$\begin{array}{l}\text { Hometown of the } \\
\text { students }\end{array}$} & Town & 213 & 267 & 480 & Reference & Reference & & \\
\hline & Village & 78 & 130 & 208 & $1.3(1.0-1.9)$ & 0.094 & & \\
\hline
\end{tabular}




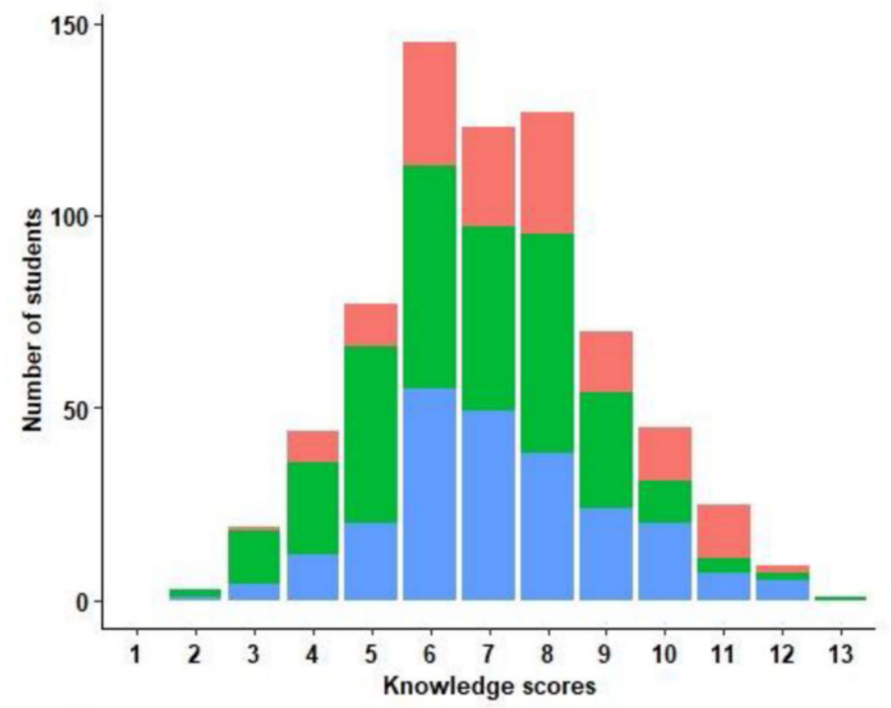

a

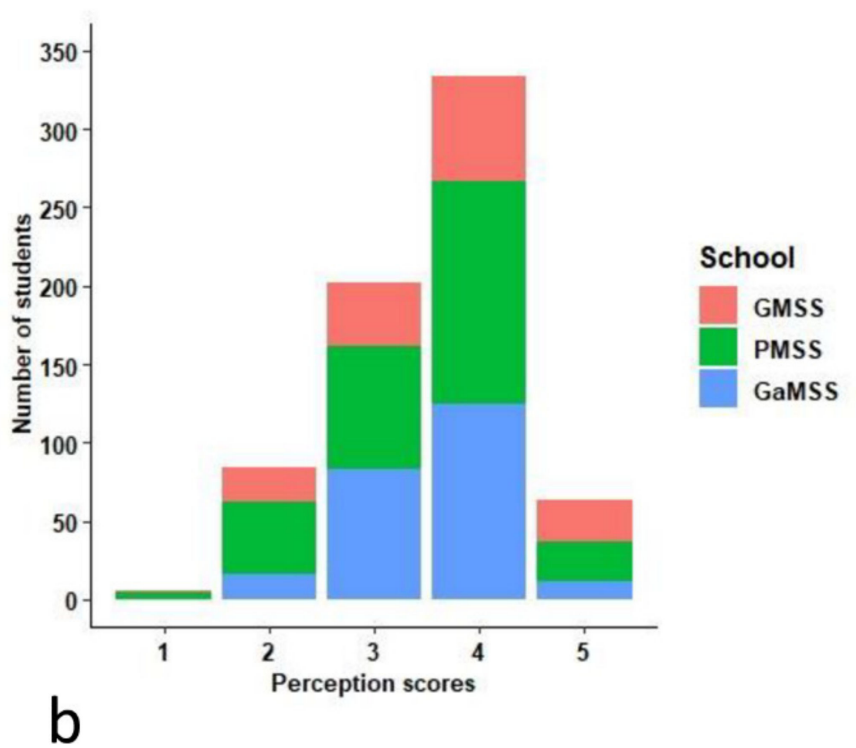

Figure 5. Distribution of knowledge and perception scores among students of three selected school: (a) Knowledge scores; (b) Perception scores.

\section{Discussion}

Our study indicated that most students (98\%) surveyed in rabies endemic areas of the country have heard about rabies and have a good level of knowledge, including the source of the disease, susceptible hosts, route of transmission, clinical signs, and preventive measures. This high awareness among students may be due to frequent reports of rabies outbreaks in the study areas, in addition to the rabies awareness campaigns conducted by the government. In Bhutan, the animal and public health officials conduct an annual education campaign related to dog bite prevention and rabies, coinciding with World Rabies Day (28th September). In addition to the general awareness program broadcasts by radio and television on rabies, the specific awareness education program is also organized in the schools. The school children also take part in the street walk in rabies endemic areas disseminating messages on the importance of dog vaccination and prevention of dog bites, among others. With most of the students citing health officials and teachers as important sources of knowledge about rabies, our findings indicate the benefits of rabies awareness programs in schools. However, the role of the teachers as information disseminating agents particularly for school children is not well recognized. In the current situation, they are rarely engaged in rabies preventive and control measures other than providing the logistic support during rabies awareness programs in their schools. Therefore, inclusion of teachers as one of key stakeholders in future rabies preventive and control measures would help to improve the level of knowledge of school children on rabies. The knowledge on rabies among students in this study is comparable to the adult population in the country $[7,10,13]$ but higher than students from the neighboring Sikkim state of India (81\%) studying in similar grades [20]. Although a majority of the students had a good level of general knowledge on rabies, some important gaps were identified (Table 2). The students usually did not know the fatal nature of the disease, that dogs are the most important sources of rabies, and that they must visit a hospital for PEP following dog bites, as local treatments are not efficient to prevent the disease. Studies conducted among students in India [20,21], Sri Lanka [22]), the Philippines [23], and Nigeria [24] have reported similar knowledge gaps, underlining the associated risks and the need for the specific rabies education in school children in rabies endemic areas. The knowledge and awareness of rabies was reported to be associated positively with several factors including the age of the respondents [25], sex [26,27], education level [20], dog ownership status [28], economic status [10], and religion [29]. Our study results showed that rabies knowledge in endemic areas of Bhutan 
was associated with the education level (grades) of the students. This result was expected because students studying in higher grades tend to have greater academic knowledge and a better understanding of the subjects in biology and health compared to lower grades. Similar observations were also reported for school children in the Sikkim State of India [20]. Among the three selected schools in southern Bhutan, students of GMSS had a better knowledge than the two other towns, which may be associated with high incidence of rabies in animals, dog bites, and PEP events in Gelephu [10,14], and a higher percentage of dog ownership [30]. A KAP study conducted among the adult population in Gelephu also demonstrated a higher understanding and knowledge of rabies compared to other areas of the country [10]. The higher level of knowledge demonstrated by students who had attended the rabies awareness program also indicated the importance of these programs as a means of rabies information dissemination, particularly for school children. As discussed previously, rabies awareness programs are provided to students on World Rabies Day, and also following rabies outbreaks. Improvement in knowledge after rabies education has been reported in other countries [20,22,23,28,31].

Globally, dog bites are responsible for more than $99 \%$ of rabies cases [3]. Therefore, thorough washing of bite wounds with soap and water and appropriate administration of PEP (including infiltration of RIG) are the only efficient methods to prevent rabies after a bite by a rabid dog [3,32]. Our study showed that most of the students had a favorable attitude and perceptions towards post-bite care and management. However, 13 students $(11.7 \%)$ who had been bitten by dogs before our study had not visited the hospital and only sought local treatment (Table 3). This is of great concern since it would prove fatal if bitten by a rabid dog. Most of the human mortalities in rabies endemic countries occur following inefficient health-seeking behaviors by dog bite victims, who cannot, or do not want to, access appropriate medical treatment and resort to local treatments $[4,19,21,33,34]$. Furthermore, the students in our survey mentioned that they would try to catch and take a sick dog to a veterinary hospital for treatment. Although it is a good attitude on animal welfare grounds, this will put children at risk of contracting rabies. Therefore, it is important to educate children on the health risks of such practices and make them aware of whom to report the incidents in their locality or school premises. Our study also showed that children whose mothers are formally employed displayed a more favorable attitude towards post-bite care and rabid dogs. Possible reasons could be due to easy access to the rabies education materials by employed mothers, who might share with their children, since they may have greater education qualifications compared to some self-employed mothers. However, differences in roles played by employed mothers and self-employed mothers and their nature of interaction with the children need to be explored further, which can be used strategically in planning future rabies education programs.

In addition to the KAP of students on rabies, we also collected data/information related to dog ownership in the study areas. Among various methods to estimate dog population, interviewing school children is also one of the methods to estimate the dog population and vaccination coverage [35]. Our survey found that $31.0 \%(n=217)$ of the students owned one or more dogs at home, which agrees with previous community studies conducted in Bhutan [30]. Although most of the students reported that the dogs they owned were vaccinated (73.0\%), dog management appeared poor since most dogs were allowed to roam freely. Mixing with unowned and free-roaming dogs increases the risk of rabies virus transmission and can result in an increase in dog populations through uncontrolled reproduction.

\section{Conclusions}

Overall, our study in rabies endemic areas of Southern Bhutan showed that most students have a good knowledge and a favorable perception towards rabies. However, some knowledge gaps and unfavorable perceptions were identified that could put school children at risk of rabies acquisition. Therefore, regular rabies awareness programs is needed, particularly for school children who are studying in lower grades. In a limited 
resource setting, priority should be given to schools that are in an area where there is a greater number of rabies cases and a low level of knowledge (e.g., Phuntsholing and Samdrup Jongkhar). Moreover, our study also highlights the important role that could be played by school teachers in dissemination of rabies information for inclusion in future rabies preventive and control programs.

Supplementary Materials: The following are available online at https:/ / www.mdpi.com/2414-636 6/6/1/28/s1, Table S1: Scoring system, Table S2: Knowledge, Attitude and Practice survey data.

Author Contributions: Conceptualization, L.L., T.T., W.P., and M.d.G.-W.; formal analysis, L.L., S.R., and T.T.; investigation, L.L. and M.d.G.-W.; data curation, L.L.; writing-original draft preparation, L.L.; writing-review and editing, L.L., S.R., T.T., W.P., and M.d.G.-W.; visualization, L.L.; supervision, L.L., S.R., T.T., W.P., and M.d.G.-W.; project administration, W.P. and M.d.G.-W. All authors have read and agreed to the published version of the manuscript.

Funding: L.L., W.P., and M.d.G.-W were supported by CIRAD/GREASE network (www.greasenetwork.org/). M.d.G.-W was supported by the French Agence Nationale de Recherche (ANR-19-ASIE0002, SEA-dog-SEA). The study was also partially supported by graduate school of Kasetsart University.

Institutional Review Board Statement: The study was approved by the Research Ethics Board of Health, Ministry of Health, Bhutan (Ref. No. REBH/Approval/2019/113).

Informed Consent Statement: Informed consent was obtained from all subjects involved in the study.

Data Availability Statement: Supplementary Materials, Table S2: Knowledge, Attitude and Practice survey data.

Acknowledgments: We thank all students for their participation in this study amid the COVID-19 pandemic. We are grateful to the Ministry of Education and the Department of Livestock, Bhutan, for providing support and the approval to conduct this study. Our special thanks go to Flavie Goutard, InterRisk master coordinator, who helped to secure the funds for the field work of the first author from CIRAD/GREASE network. We are also thankful to the graduate school of Kasetsart University for partial fund support of the study.

Conflicts of Interest: The authors declare that there are no conflicts of interest regarding the publication of this paper. The funders had no role in the design of the study; in the collection, analyses, or interpretation of data; in the writing of the manuscript; or in the decision to publish the results.

\section{References}

1. Okello, A.L.; Beange, I.; Shaw, A.; Moriyón, I.; Gabriël, S.; Bardosh, K.; Johansen, M.V.; Saarnak, C.; Mukaratirwa, S.; et al.; ICONZ. Raising the political profile of the neglected zoonotic diseases: Three complementary European commission-funded projects to streamline research, build capacity and advocate for control. PLoS Negl. Trop. Dis. 2015, 9, e0003505. [CrossRef]

2. Hampson, K.; Coudeville, L.; Lembo, T.; Sambo, M.; Kieffer, A.; Attlan, M.; Barrat, J.; Blanton, J.D.; Briggs, D.J.; Cleaveland, S.; et al. Estimating the global burden of endemic canine rabies. PLoS Negl. Trop. Dis. 2015, 9, e0003709. [CrossRef]

3. World Health Organization. WHO Expert Consultation on Rabies: Third Report; World Health Organization: Geneva, Switzerland, 2018.

4. Digafe, R.T.; Kifelew, L.G.; Mechesso, A.F. Knowledge, attitudes and practices towards rabies: Questionnaire survey in rural household heads of Gondar Zuria District, Ethiopia. BMC Res. Notes 2015, 8, 400. [CrossRef]

5. Tiwari, H.K.; Robertson, I.D.; O'Dea, M.; Vanak, A.T. Knowledge, attitudes and practices (KAP) towards rabies and free roaming dogs (FRD) in Panchkula district of north India: A cross-sectional study of urban residents. PLoS Negl. Trop. Dis. 2019, 13 e0007384. [CrossRef] [PubMed]

6. Tenzin, T.; Dhand, N.K.; Ward, M.P. Patterns of rabies occurrence in Bhutan between 1996 and 2009. Zoonoses Public Health 2011, 58, 463-471. [CrossRef] [PubMed]

7. Tenzin, T.; Namgyal, J.; Letho, S. Community-based survey during rabies outbreaks in Rangjung town, Trashigang, eastern Bhutan, 2016. BMC Infect. Dis. 2017, 17, 281. [CrossRef] [PubMed]

8. Tenzin, T.; Sharma, B.; Dhand, N.K.; Timsina, N.; Ward, M.P. Reemergence of rabies in Chhukha district, Bhutan, 2008. Emerg. Infect. Dis. 2010, 16, 1925-1930. [CrossRef]

9. Penjor, K.; Tenzin, T.; Jamtsho, R.K. Determinants of health seeking behavior of animal bite victims in rabies endemic South Bhutan: A community-based contact-tracing survey. BMC Public Health 2019, 19, 237. [CrossRef]

10. Tenzin, T.; Dhand, N.K.; Rai, B.D.; Tenzin, S.; Tsheten, K.; Ugyen, P.; Singye, K.; Ward, M.P.; Changlo. Community-based study on knowledge, attitudes and perception of rabies in Gelephu, south-central Bhutan. Int. Health 2012, 4, 210-219. [CrossRef] [PubMed] 
11. Tenzin, T.; Rinzin, K.; Penjor, K.; Dukpa, K.; Jamtsho, R.K.; Phuentshok, Y.; Mahat, H.; CHoden, K.; Gyeltshen, K.; Darnal, J.B. Rabies Prevention and Control Program in Bhutan: Self-assessment using SARE Tool. Bhutan J. Anim. Sci. 2019, 3, 66-76.

12. Rai, R. Three-Year-Old Girl Dies of Rabies in Samtse Kuensel. Available online: https://kuenselonline.com/three-year-old-girldies-of-rabies-in-samtse (accessed on 26 December 2020).

13. Rinchen, S.; Tenzin, T.; Hall, D.; van der Meer, F.; Sharma, B.; Dukpa, K.; Cork, S. A community-based knowledge, attitude, and practice survey on rabies among cattle owners in selected areas of Bhutan. PLoS Negl. Trop. Dis. 2019, 13, e0007305. [CrossRef] [PubMed]

14. Tenzin, T.; Dhand, N.; Gyeltshen, T.; Firestone, S.; Zangmo, C.; Dema, C.; Gyeltshen, R.; Ward, M. Dog Bites in Humans and Estimating Human Rabies Mortality in Rabies Endemic Areas of Bhutan. PLoS Negl. Trop. Dis. 2011, 5, e1391. [CrossRef] [PubMed]

15. NSB. Population \& Housing Census of Bhutan. National Report. 2018. Available online: www.nsb.gov.bt (accessed on 26 December 2020).

16. CDC. Epi Info ${ }^{\mathrm{TM}}$ for Windows. Available online: https://www.cdc.gov/epiinfo/pc.html (accessed on 27 April 2020).

17. R Core Team. R: A Language and Environment for Statistical Computing; R Foundation for Statistical Computing: Vienna, Austria, 2019.

18. Chandan, N.; Kotrabasappa, K. Awareness of animal bite and rabies among agricultural workers in rural Dharwad, Karnataka, India. Int. J. Community Med. Public Health 2016, 3, 1851-1855. [CrossRef]

19. Tripathy, R.; Satapathy, S.; Karmee, N. Assessment of knowledge, attitude and practice regarding rabies and its prevention among construction workers: A cross-sectional study in Berhampur, Odisha. Int. J. Res. Med. Sci. 2017, 5, 3971-3975. [CrossRef]

20. Auplish, A.; Clarke, A.S.; Van Zanten, T.; Abel, K.; Tham, C.; Bhutia, T.N.; Wilks, C.R.; Stevenson, M.A.; Firestone, S.M. Estimating the intra-cluster correlation coefficient for evaluating an educational intervention program to improve rabies awareness and dog bite prevention among children in Sikkim, India: A pilot study. Acta Trop. 2017, 169, 62-68. [CrossRef]

21. Sancheti, P.V.; Mangulikar, S.K. An interventional study to assess knowledge regarding rabies in secondary school students. Int. J. Community Med. Public Health 2016, 3, 180-183. [CrossRef]

22. Matibag, G.; Obayashi, Y.; Kanda, K.; Yamashina, H.; Kumara, B.; Perera, I.N.; de Silva, N.; Gunawardena, P.; Jayasinghe, A.; Ditangco, R.; et al. A pilot study on the usefulness of information and education campaign materials in enhancing the knowledge, attitude and practice on rabies in rural Sri Lanka. J. Infect. Dev. Ctries. 2009, 3, 55-64. [CrossRef] [PubMed]

23. Amparo, A.C.B.; Mendoza, E.C.; Licuan, D.; Valenzuela, L.; Madalipay, J.; Jayme, S.I.; Taylor, L. Impact of integrating rabies education into the curriculum of public elementary schools in Ilocos Norte, Philippines on rabies knowledge and animal bite incidence. Front. Public Health 2019, 7, 119. [CrossRef] [PubMed]

24. Dzikwi, A.A.; Ibrahim, A.S.; Umoh, J.U. Knowledge, attitude and practice about rabies among children receiving formal and informal education in Samaru, Zaria, Nigeria. Glob. J. Health Sci. 2012, 4, 132-139. [CrossRef]

25. Krishnamoorthy, Y.; Vijayageetha, M.; Sarkar, S. Awareness about rabies among general population and treatment seeking behaviour following dog-bite in rural Puducherry: A community based crosssectional study. Int. J. Community Med. Public Health 2018, 5, 2557-2563. [CrossRef]

26. Palamar, M.B.; Peterson, M.N.; Deperno, C.S.; Correa, M.T. Assessing rabies knowledge and perceptions among ethnic minorities in Greensboro, North Carolina. J. Wildl. Manag. 2013, 77, 1321-1326. [CrossRef]

27. Sambo, M.; Lembo, T.; Cleaveland, S.; Ferguson, H.M.; Sikana, L.; Simon, C.; Urassa, H.; Hampson, K. Knowledge, Attitudes and Practices (KAP) about Rabies Prevention and Control: A Community Survey in Tanzania. PLoS Negl. Trop. Dis. 2014, 8, e3310. [CrossRef]

28. Burdon Bailey, J.L.; Gamble, L.; Gibson, A.D.; Bronsvoort, B.M.d.; Handel, I.G.; Mellanby, R.J.; Mazeri, S. A rabies lesson improves rabies knowledge amongst primary school children in Zomba, Malawi. PLoS Negl. Trop. Dis. 2018, 12, e0006293. [CrossRef] [PubMed]

29. Kabeta, T.; Deresa, B.; Tigre, W.; Ward, M.P.; Mor, S.M. Knowledge, Attitudes and Practices of Animal Bite Victims Attending an Anti-rabies Health Center in Jimma Town, Ethiopia. PLoS Negl. Trop. Dis. 2015, 9, e0003867. [CrossRef] [PubMed]

30. Rinzin, K.; Tenzin, T.; Robertson, I. Size and demography pattern of the domestic dog population in Bhutan: Implications for dog population management and disease control. Prev. Vet. Med. 2016, 126, 39-47. [CrossRef] [PubMed]

31. Hasanov, E.; Zeynalova, S.; Geleishvili, M.; Maes, E.; Tongren, E.; Marshall, E.; Banyard, A.; McElhinney, L.M.; Whatmore, A.M.; Fooks, A.R.; et al. Assessing the impact of public education on a preventable zoonotic disease: Rabies. Epidemiol. Infect. 2018, 146, 227-235. [CrossRef]

32. Hemachudha, T.; Laothamatas, J.; Rupprecht, C.E. Human rabies: A disease of complex neuropathogenetic mechanisms and diagnostic challenges. Lancet Neurol. 2002, 1, 101-109. [CrossRef]

33. Bouaddi, K.; Bitar, A.; Bouslikhane, M.; Ferssiwi, A.; Fitani, A.; Mshelbwala, P.P. Knowledge, Attitudes, and Practices Regarding Rabies in El Jadida Region, Morocco. Vet. Sci. 2020, 7, 29. [CrossRef]

34. Ghosh, S.; Chowdhury, S.; Haider, N.; Bhowmik, R.K.; Rana, M.S.; Prue Marma, A.S.; Hossain, M.B.; Debnath, N.C.; Ahmed, B.-N. Awareness of rabies and response to dog bites in a Bangladesh community. Vet. Med. Sci. 2016, 2, 161-169. [CrossRef] [PubMed]

35. Sambo, M.; Johnson, P.C.D.; Hotopp, K.; Changalucha, J.; Cleaveland, S.; Kazwala, R.; Lembo, T.; Lugelo, A.; Lushasi, K.; Maziku, M.; et al. Comparing Methods of Assessing Dog Rabies Vaccination Coverage in Rural and Urban Communities in Tanzania. Front. Vet. Sci. 2017, 4. [CrossRef] 